\title{
Penerapan Laporan Keuangan Masjid Jami' Al-Hidayah Pondok Bambu sesuai PSAK 45
}

\author{
Ari Purwanti ${ }^{1}$, Adi Riyanto ${ }^{2}$ \\ 1, 2 Universitas Islam As-Syafi'iyah, Bekasi, Indonesia \\ *E-mail:aripurwanti2510@gmail.com
}

\begin{abstract}
Abstrak
Pengabdian masyarakat ini diselenggarakan pada Masjid Jami' Al-Hidayah yang berlokasi di Jl. Pondok Bambu Asri Raya No.10 RW.09 Kelurahan Pondok Bambu, Kecamatan Duren Sawit, Jakarta Timur. Penentuan masjid ini berasal dari permintaan dari pengawas masjid untuk membantu mencarikan cara bagaimana pelaporan keuangan yang efektif dan memiliki standar. Metode pelaksanaan pengabdian masyarakat ini diselenggarakan dengan serangkaian metode dalam 3 tahap, yaitu tahap pengumpulan data, tahap penyusunan dan implementasi teknis, dan tahap evaluasi. Pada tahap 1 dilakukan beberapa metode pengumpulan data, di antaranya: wawancara, observasi, dan pendokumentasian. Tahap 2 merupakan tahap penyusunan langkah-langkah pelaporan dan implementasi. Setelah memperoleh data, mulailah disusun langkah-langkah pelaporan keuangan berdasarkan PSAK 45 dan kemudian dibuat format excel link-nya sesuai dengan bagan alir kegiatan keuangan masjid. Setelah itu dicobakan dan dilakukan pendampingan terhadap pengurus y ang akan menggunakan sistemakuntansi. Tahap 3 adalah tahap evaluasi yang bertujuan untuk mengetahui tingkat keberhasilan penerapan dan kenyamanan pemakai sistem akuntansi.
\end{abstract}

Kata Kunci: masjid; pelaporan keuangan; excel accounting.

\begin{abstract}
This community service was held at the Jami 'Al-Hidayah Mosque, located on Jl. Pondok Bambu Asri Raya No.10 RW.09 Pondok Bambu Village, Duren Sawit District, East Jakarta. The determination of this mosque came from a request from the mosque supervisor to help find a way of how to provide effective and standardized financial reporting. This method of implementing community service is carried out by a series of methods in 3 stages, namely the data collection stage, the technical preparation and implementation stage, and the evaluation stage. In stage 1, several datacollection methods were carried out, including: interviews, observation, and documentation. Stage 2 is the stage of preparing the reporting and implementation steps. After obtaining the data, begin to compile the steps for financial reporting based on PSAK 45 and then create an excel linkformat according to theflow chant of mosque financial activities. After that, it is tested and provided assistance to the management who will use the accounting system. Stage 3 is the evaluation stage which aims to determine the level of success of the application and the comfort of the accounting system users.
\end{abstract}

Keywords: mosque; finance report; excel accounting. 


\section{PENDAHULUAN}

Masjid merupakan bagian dari entitas publik nirlaba yang salah satunya fungsi masjid adalah untuk mengelola dana dari publik, baik dana sedekah, wakaf, infaq, maupun zakat. Untuk dapat membuat laporan keuangan dana masjid dengan akurat dibutuhkan penerapan akuntansi yang sederhana dan mudah diaplikasikan serta mudah dipahami oleh penggunaannya. Dengan demikian, penggunaan akuntansi yang memadai dapat memperlancar organisasi mengelola keuangannya, mulai dari perencanaan, pengawasan dan pengambilan keputusan (Halim dan Kusufi, 2012). Selain itu, keberhasilan pelaporan keuangan masjid sering kali menjadi patokan kinerja bagi pengurus masjid (takmir) (Hanafi, 2015) sebagai bentuk pertanggungjawaban kepada publik atas pengelolaan sumber dana dari masyarakat (Siskawati, Ferdawati, dan Surya, 2016 dan Latif, 2014).

Namun dalam prakteknya masih terdapat masjid-masjid yang ternyata belum melakukan penyampaian laporan keuangannya atau keuangan dilaporkan masih sekedarnya saja tanpa ada aturan baku/standar, sehingga sering kali pengelola masjid sulit untuk menelusuri sumber dan penggunaanya. Kondisi ini yang sering kali mendorong para donatur enggan atau sedikit ada keraguan apakah dana yang disumbangkan benar-benar dipergunakan sesuai kegiatan yang mereka niatkan. Oleh karena itu, dibutuhkan laporan keuangan yang dikelola baik dan transparan (Andarsari, 2016). Kelemahan-kelemahan yang masih terjadi di masjid di antaranya pengurus masjid dalam menjalankan kegiatan operasinya (masjid) hanya mengandalkan asas kepercayaan untuk setiap kegiatan transaksi masjid, pencatatan yang kurang rapi hanya mencakup penerimaan dan pengeluaran kas tanpa memperlihatkan jumlah aset yang dimiliki oleh masjid, belum dilakukan pencatatan aset non kas yang dimiliki masjid, sehingga hal ini membuat sulitnya mengetahui posisi keuangan masjid yang sebenarnya, masjid hanya menggunakan satu rekening yang banyak ditemukan rekening pribadi sehingga dan yang masuk tercampur aduk dalam satu rekening sehingga besar kemungkinan dana tersebut tidak tepat dalam pendistribusiannya.

Kasus seperti ini terjadi pada masjid Jami’ Al-Hidayah. Meski sudah membuat laporan keuangan, namun hanya sebatas penerimaan dan pengeluaran kas saja dan tidak terorganisir dengan baik. Bukti transaksi tidak disusun berdasar kegiatan aliran kas dan jenis kegiatannya. Bahkan, ada beberapa yang ditemukan tidak ada bukti transaksinya. Kondisi ini sering kali menjadi permasalahan pada saat muncul laporan pertanggungjawaban kegiatan.

Untuk itu dibutuhkan suatu sistem pencatatan akuntansi yang sederhana yang mudah dipahami dan diaplikasikan bagi pengurus masjid, dan dapat evaluasi, serta mudah pelaporannya. Sesuai dengan PSAK No. 45 tahun 2011 tentang organisasi nirlaba, bahwa organisasi nirlaba harus dan berhak untuk membuat laporan keuangan dan melaporkan kepada para pemakai laporan keuangan. Maka, lembaga masjid harus dan berhak untuk membuat laporan keuangan yang sesuai standar PSAK No. 45 dan melaporkan kepada pemakai laporan keuangan lembaga masjid. PSAK No. 45 juga menyatakan bahwa tujuan utama laporan keuangan adalah menyediakan informasi yang relevan untuk memenuhi kepentingan para penyumbang, anggota organisasi, kreditur, dan pihak lain yang menyediakan sumber daya bagi organisasi nirlaba.

Pembuatan laporan keuangan tentu memerlukan alat bantu yang akan mempermudah pekerjaannya. Microsoft Excel adalah program aplikasi yang umum dan mudah digunakan (user friendly) dalam pembuatan tabel dan menghitung. Tentunya, hal ini berkaitan dengan pembuatan laporan keuangan. Sehingga Microsoft Excel dapat dijadikan sebagai alat bantu sistem akuntansi pembuatan laporan keuangan. 
Melihat fenomena diatas maka perlu adanya usualan dalam rangka mewujudkan pelaporan yang benar untuk organisasi nirlaba keagaman sesuai yang dikeluarkan oleh IAI. Dengan aplikasi Micosoft Excel sebagai alat bantu dalam rangka penyusunan laporan keuangan masjid diharapkan efektifitas dan efisiensi dalam pelaporan keuangan dapat diwujudkan dengan baik. Untuk itu, berdasarkan latar belakang yang terjadi pada pelaporan keuangan Masjid Jami’ Al-Hidayah, maka melalui kegiatan pengabdian masyakat, Kami membantu menerapkan pelaporan keuangan masjid sesuai PSAK 45.

\section{METODE}

Pelaksanaan pengabdian masyarakat ini dilakukan di Masjid Jami’ Al-Hidayah yang berlokasi di J1. Pondok Bambu Asri Raya No.10 RW.09 Kelurahan Pondok Bambu, Kecamatan Duren Sawit, Kota Adm. Jakarta Timur. Penentuan masjid ini berasal dari permintaan dari pengawas masjid untuk membantu mencarikan carabagaimana pelaporan keuangan yang efektif dan memiliki standar.

Metode pelaksanaan pengabdian masyarakat ini diselenggarakan dengan serangkaian metode dalam 3 tahap. Tahap 1 adalah tahap pengumpulan data. Tahap 2 adalah tahap penyusunan dan implementasi teknis dan Tahap 3 adalah tahap evaluasi.

Pada tahap 1 dilakukan beberapa metode pengumpulan data, di antaranya: wawancara, observasi, dan pendokumentasian. Wawancara dilakukan untuk memperoleh penjelasan dengan menggunakan tanya jawab (tatap muka). Kemudian, dilanjutkan dengan observasi untuk mendapatkan informasi riil atas transaksi dan kegiatan keuangan masjid lainnya. Hal-hal yang diobsevasi adalah dokumen yang digunakan dan prosedur yang membentuk pelaporan keuangan yang dipakai Masjid Jami' Al-Hidayah Pondok Bambu. Selanjutnya adalah pendokumentasian bukti y ang ada, apakah berupa bentuk buku catatan, arsip, dokumen lain, dan laporan keuangan periode-periode sebelumnya.

Tahap 2 merupakan tahap penyusunan langkah-langkah pelaporan dan implementasi. Setelah memperoleh data, mulailah disusun langkah-langkah pelaporan keuangan berdasarkan PSAK 45 dan kemudian dibuat format excel link nya sesuai dengan bagan alir kegiatan keuangan masjid. Setelah itu dicobakan dan dilakukan pendampingan terhadap pengurus yang akan menggunakan sistem akuntansi.

Tahap 3 adalah tahap evaluasi yang bertujuan untuk mengetahui tingkat keberhasilan penerapan dan kenyamanan pemakai sistem akuntansi.

\section{HASIL DAN PEMBAHASAN}

Pelaksanaan tahap 1 berlangsung selama 1 minggu, 4 kali pertemuan dengan pengurus dan bendahara masjid dengan durasi diskusi sekitar 1,5 sampai 2 jam. Hasilnya, visualisasi bukti fisik, proses pencatatan $\mathrm{m}$ pendokumentasian, dan pelaporan yang selama ini berjalan. Kegiatan masjid pun dapat diinventarisir, mulai dari sedekah, infaq, zakat, majlis taklim, pemeliharaan gedung masjid, inventarisir peralatan, konsumsi, dan gaji pengurus harian. Hasilnya, ada beberapa hal yang menjadi catatan untuk perbaikan dan semua nya dicatat sebagai dasar pelaksanaan tahap 2, di antaranya:

1. Informasi yang ada pada catatan adalah informasi penerimaan dan pengeluaran kas yang tidak dimasukan ke dalam jurnal umum.

2. Informasi diatas tidak sesuai standar akuntansi yang mengacu pada metode double entry, sehingga kurang akuntabel. 
3. Penyampaian informasi tentang uraian dalam tabel kurang jelas, sehingga hanya orang yang bersangkutan yang mengetahuinya dan hal ini menyebabkan susah dalam pemindahan ke jurnal umum atau kegiatan penjumalan.

4. Saldo tidak dijelaskan secara mendetail karena tidak adanya pengelompokan akun ke dalam jurnal umum.

5. Manual input sering terjadi kesalahan pada penulisan tanggal transaksi.

Pelaksanaan tahap 2 dimulai dengan perancangan susunan langkah-langkah dalam pelaporan keuangan berdasarkan hasil dan data dari tahap 1. Kegiatan perancangan ini dimulai dengan mengorganisir bukti transakti sesuai dengan kegiatan operasi masjid. Untuk itu, dibuatlah akun untuk setiap kegiatan dan mulai untuk memberikan kode pada akun kegiatan, seperti pada tabel 1. Selanjutnya, merancang pencatatan melalui jurnal sederhana dengan menggunakan Ms Excel. Pada bagian ini, sekaligus juga dilakukan pendampingan bagi pengurus untuk mempelajari bagaimana melakukan penjurnalan secara sederhana berkaitan dengan aliran kas masuk dan keluar.

Tabel 1. Daftar Kegiatan Masjid

\begin{tabular}{|c|c|c|c|c|}
\hline \multicolumn{2}{|c|}{ No } & \multirow[b]{2}{*}{ Saldo Awal } & \multirow[t]{2}{*}{ Desember } & \multirow[t]{2}{*}{ Jumlah } \\
\hline & 0 & & & \\
\hline & & Kas: & 0.653 .594 & \\
\hline \multirow[t]{23}{*}{ 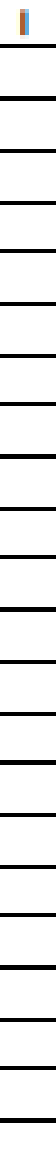 } & PLNE & MAN & 98.005.49 & $\mathrm{xxx}$ \\
\hline & 1.1. & KOTAK AMAL & 36.520 .000 & $\mathrm{xwx}$ \\
\hline & & 1.1.1. Kotak Amal Jumat & 0 & $x x$ \\
\hline & & 1.1.2. Kotak Amal lidul Fitri/Idul Adhat & 0 & $x \times x$ \\
\hline & & 1.1.3. Kotak Amal ramadhan & 0 & $\mathrm{xxx}$ \\
\hline & & 1.1.4. Kotak Amal Pengojlan & 0 & $\mathrm{xxx}$ \\
\hline & 1.2. & ZAKAT, INFAQ, SHADAOOH (ZIS) & 4.92500 & $\mathrm{xix}$ \\
\hline & & 1.2.1. Zakat Mal & 2.00000 & $\mathrm{xwx}$ \\
\hline & & 1.2.2. Zakat. Fitrah dan Fidiyah & 号 & $\mathrm{wx}$ \\
\hline & & 1.2.3. Infag Shadaqoh [Amal Jariyah] & 2.9250 & $x x$ \\
\hline & & 1.2.4. Infag Kegiatan Khusus & o & $x x x$ \\
\hline & 1.3. & DONATUA & 0 & $\mathrm{xxx}$ \\
\hline & & 1.3.1. Donatur Tetap & 0 & $x x$ \\
\hline & & 1.3.2. Donatur Tidak Tetap & 0 & $\mathrm{xx}$ \\
\hline & 1.4. & EDDANG USAHA & 12.300000 & $\sin$ \\
\hline & & 1.4.1. Sewa Kos & 7.50000 & $x x$ \\
\hline & & 1.4.2. Sewa Gedung Serba Guna & 4.00000 & $x x$ \\
\hline & 1.5. & EIDANG PENDIDIKAN & 2.920000 & $x x x$ \\
\hline & & 1.5.1. Kontribusi SPP TK Islam/Santri TPA & 2.920000 & $x x$ \\
\hline & 1.6. & KCGIATAN LAIN-LAIN & 2.170649 & $\mathrm{xix}$ \\
\hline & & 1.6.1. Ambulante & 1.950 .000 & $x x$ \\
\hline & & 1.6.2 Mobil Operaianal & 0 & $x x$ \\
\hline & & 1.6.3. Lain-Lain & 20.20 .649 & $x x x$ \\
\hline
\end{tabular}


CAPACITAREA, Vol. 1 (2020)

Penerapan Laporan Keuangan Masjid Jami' Al-Hidayah Pondok Bambu sesuai PASAK 45

Ari Purwanti, Adi Riyanto

\begin{tabular}{|c|c|c|c|c|}
\hline \multicolumn{2}{|c|}{ No } & Uraian & Desember & Jumlah \\
\hline & 0 & Saldo Awal & & \\
\hline & & Kas & 00.653.594 & \\
\hline \multirow[t]{38}{*}{ II } & \multicolumn{2}{|c|}{ PENGELUARAN } & 100.71 .349 & mar \\
\hline & 21. & SEKAETARIAT & 4.122200 & mat \\
\hline & & 2.1.1. Perlen dkapanjPeralatan Kantor & t & $\mathrm{mar}$ \\
\hline & & 212 Admin btrasi Kese kretariatian & 158210 & $\mathrm{mar}$ \\
\hline & & 2.1. Alat Tulls Kantor & a & nor \\
\hline & & 2.1.4. Snadk/konsumsi rapat Panitia & 1.794.000 & mat: \\
\hline & & 2.1.5. Coffee Moming'Buka Puaga S/K & 吾 & $\mathrm{mar}$ \\
\hline & & 2.1.t. Spanduk/Frer/barang Cetakan & cotoog & $\mathrm{ma}$ \\
\hline & & 2.1.7. Bulletin jumat//dul Fitrifldul Adha & 11000 & $\mathrm{mar}$ \\
\hline & 22 & OPERASIONAL & 34.005 .249 & $\mathrm{ma}$ \\
\hline & & 221 Honor Pettuga & 10.900 .000 & nat \\
\hline & & 222 Lstrik/Telephone/PAM & 2736.56 & nor: \\
\hline & & 221. Trarsport & (9) & nor: \\
\hline & & 224. Lin-Lin & 20.364.6eg & nor: \\
\hline & 23. & DAKWAH DAN KEMASIIDAN & 11.394 .000 & nat: \\
\hline & & 23.1 Khatib Jumat & 1.00000 & $\mathrm{mar}$ \\
\hline & & 23.2 Khatib lidul Fitri/Adha & 0 & mar \\
\hline & & 221. Pengajian Bulanan & 1.80000 & not \\
\hline & & 224. Pengajian MTAH & 1.00ubo & $\mathrm{na}$ \\
\hline & & 22.5. Peringatan Hari Besar lsham & t & nor \\
\hline & & 2.6. Indm, Bilal R Cerameh Ramadhan & t & $\mathrm{mat}$ \\
\hline & & 2.2. Pemyluran Zikat Fitrah B Fidrah & a & nor: \\
\hline & & 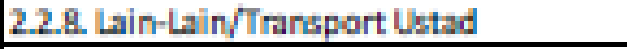 & 4.544.000 & $\mathrm{mar}$ \\
\hline & 24 & PENDIDIKAN & 15.900 .900 & $\mathrm{ma}$ \\
\hline & & 24.1 Honor Guru TK 2 TPA & 11.300 .000 & $\mathrm{nor}$ \\
\hline & & 242 Kegatan Lin-Lain & 4.ceusu & $\mathrm{ma}$ \\
\hline & 25 & SAPANA DAN PALSARANA & SE.281.00 & $\mathrm{nar}$ \\
\hline & & 2.5.1 Perbaikan Gedung serba Guna & t & nor: \\
\hline & & 2.5.2 Perawattan Bangunan R Taman & 130000 & $\mathrm{na}$ \\
\hline & & 2.5.1. Perbaikan Service AC/Lampu & 94.000 & $\mathrm{mar}$ \\
\hline & & 2.54. Peralatan 2 Perlengkapsn & 36.587 .000 & $\mathrm{mat}$ \\
\hline & & 2.5.5. Kendaraan & 牙 & $\mathrm{nor}$ \\
\hline & & 2.5.6. kebersihan & 3hong & nor \\
\hline & 2.6 & PELAYANAN JENAZAH & - & $\mathrm{mar}$ \\
\hline & & 2.6.1 Pengadaan Perlengkapan & t & nor \\
\hline & & 2.6.2 Pelaranan & d & $\mathrm{ma}$ \\
\hline & 27 & Sosial & 문 & $\mathrm{mar}$ \\
\hline & & 27.1. Bantuan Sosalf Kegiatan Zakat Mal & d & $\mathrm{mar}$ \\
\hline IIII & & SALOO AKHIR & 75.75 .84 & $\mathrm{xx}$ \\
\hline
\end{tabular}


Selanjutnya, adalah perancangan sistem akuntansi masjid. Tampilan "Home" adalah tampilan yang muncul saat pertama kali akuntansi excel dibuka (Gambar 1). Di dalam sheet home terdapat kolom (cell) yang harus diisi seperti kolom nama perusahaan, tanggal, bulan dan tahun pembuatan laporan keuangan. Pada kolom tanggal dan bulan telah divalidasi angka sebanyak jumlah angka (tanggal) dalam satu bulan dan nama-nama bulan dalam satu tahun. Kemudian pada saat memasukan tanggal, bulan dan tahun sheet berikutnya otomatis akan mengikuti tanggal, bulan dan tahun yang diinput. Hal ini akan mengurangi resiko salah penulisan tanggal, bulan dan tahun pada setiap sheet-nya. Di dalam sheet home juga terdapat menu lembar kerja yang telah di -link- kan ke masing-masing sheet-nya yaitu kode akun, jurnal umum, buku besar, saldo sebelum penyesuaian, perhitungan depresiasi, jurnal penyesuaian, saldo setelah penyesuaian, neraca saldo, laporan aktivitas, laporan posisi keuangan, laporan arus kas dan jurnal penutup.

Kegunaan dari validasi pada kolom adalah untuk meminimalisir kesalahan saat input data dan kegunaan dari link adalah memudahkan dalam membuka tiap-tiap sheet pada microsoft excel sehingga mempercepat pekerjaan. Berikut tampilan home akuntansi excel masjid jami' Al-Hidayah.

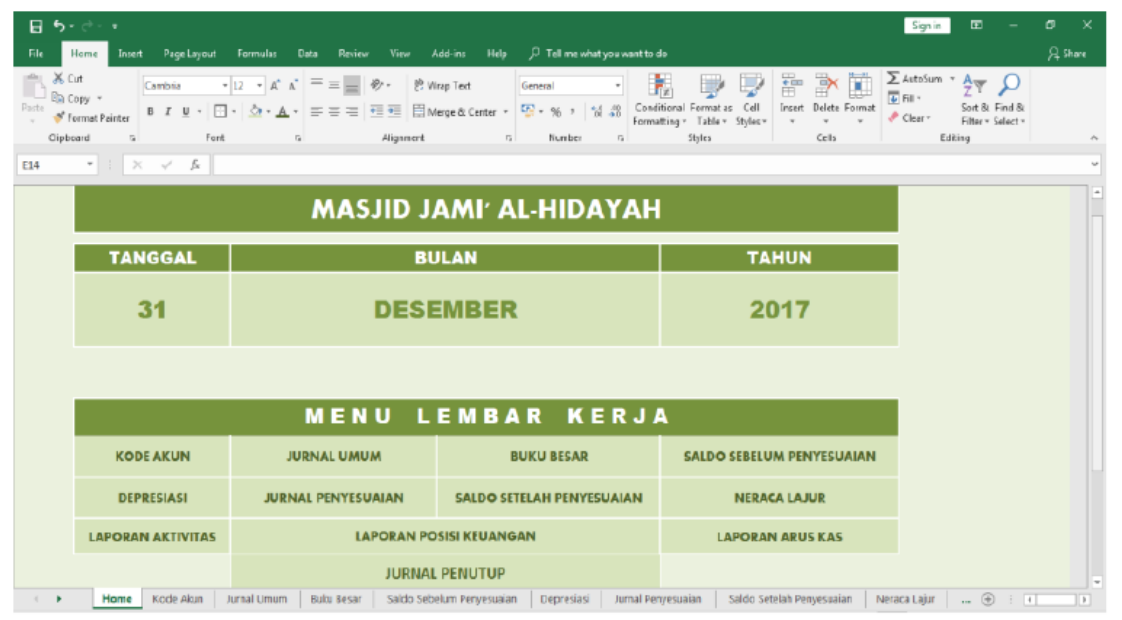

Gambar 1. Tampilan Home Excel Accounting

Dalam sheet daftar perkiraan akun terdapat kolom home, jam dan waktu. Kolom home digunakan untuk kembali ke sheet home dan kolom waktu untuk menunjukan jam, tanggal, bulan dan tahun sekarang. Di dalam tabel daftar perkiraan akun terdapat informasi mengenai kode akun, nama akun, kode bantu, pos saldo, pos laporan, saldo awal (debet/kredit) dan jenis akun.

Kolom kode akun berisi nomor akun yang sudah dibuat sesuai penomeran yang berlaku. Kolom nama akun berisi perkiraan nama akun yang dipakai dalam transaksi. Kolom kode bantu berisikan kode akun yang digunakan untuk memudahkan dalam perumusan excel. Kolom pos saldo berisi validasi debet dan kredit yang merupakan pos saldo normal dari tiap-tiap akun.

Kolom pos laporan berisi validasi laporan aktivitas dan laporan posisi keuangan yang nantinya akan dikelompokan secara otomatis pada neraca lajur. Kolom jenis akun berfungsi untuk mengetahui jenis akun tidak terikat, terikat temporer dan terikat permanen.

Selain menampilkan isi tabel yang informatif, tujuan dari validasi yang ada pada kolom pos akun, pos laporan dan jenis akun adalah mengurangi resiko salah posting pada neraca lajur yang nantinya berdampak pada salahnya pelaporan keuangan dan juga mengurangi salah input data pada kolom tersebut. Berikutnya adalah kolom saldo awal berisi saldo awal kredit dan debet. Kemudian 
yang terakhir adalah kolom jenis akun yaitu informasi mengenai akun mana yang termasuk akun tidak terikat, terikat temporer dan terikat permanen seperti pada Gambar 2.

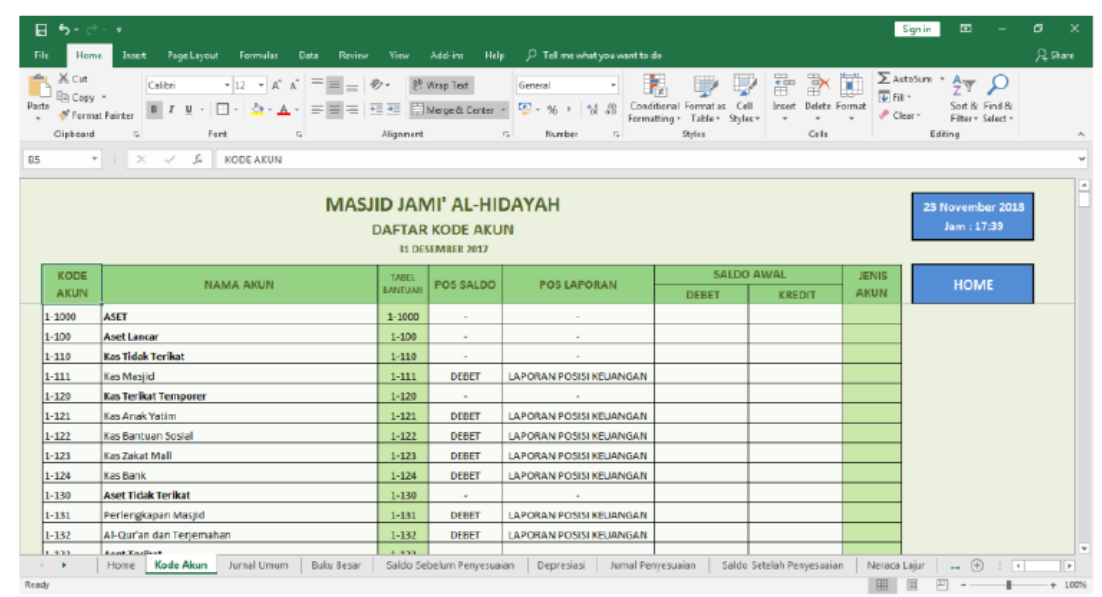

Gambar 2. Tampilan Daftar Perkiraan akun Excel Accounting

Setelah daftar perkiraan akun dibuat selanjutanya adalah membuat sheet jurnal umum. Pada sheet jurnal umum terdapat kolom home untuk kembali ke halaman utama dan kolom waktu sekarang. Pada tabel jurnal umum terdapat kolom nomor, tanggal (2 kolom), bukti transaksi, keterangan, nama akun, kode akun dan debet/kredit. Kolom nomor (No.) digunakan untuk penomeran transaksi. Kolom tanggal terdiri dari 2 kolom. Kolom yang pertama yaitu kolom validasi berupa angka yang menunjukan tanggal dan kolom yang kedua adalah tanggal/bulan/tahun yang otomatis muncul saat kolom pertama diisi.

Tujuan dari kolom tanggal ini supaya mengurangi resiko salah saat memasukan tanggal dan mudah mengganti saat salah memasukan tanggal. Kolom kode bukti diisi jika transaksi mempunyai kode bukti tertulis. Kolom keterangan adalah kolom yang berisi transaksi yang terjadi. Berikutnya adalah kolom nama akun dan kode akun adalah kolom yang menunjukan nama akun yang di debetkredit dan kode akun akan otomatis muncul sesuai nomor akun yang dibuat pada daftar perkiraan.

Validasi yang dibuat pada kolom nama akun bertujuan untuk mengurangi resiko salah input data. Terakhir adalah kolom debet/kredit untuk mengisi saldo yang didebet dan saldo yang dikredit.

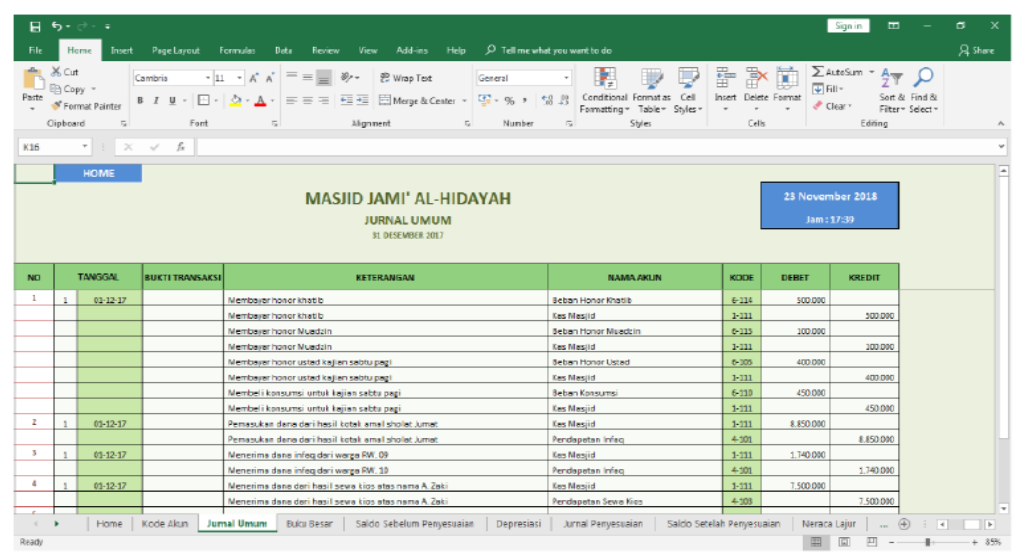

Gambar 3. Tampilan Jurnal Umum Excel Accounting 
Informasi yang terpenting dalam buku besar adalah saldo akhir dari transaksi-transaksi jurnal umum. Jumlah tabel dalam buku besar disesuaikan dengan banyaknya nama akun yang telah dibuat dalam perkiraan. Melihat hal ini peneliti membuat validasi data untuk mempermudah dalam pencarian informasi saldo akhir tiap-tiap akun. Tujuan dari validasi adalah untuk menghindari salah input data nama akun. Selain itu ada dua kolom yang menampilkan nomor akun dan pos akun secara otomatis sesuai nama akun.

Hal ini dibuat untuk menjadikan halaman buku besar lebih informatif. Dalam sheet buku besar terdapat kolom pencarian nama akun, kode akun, pos saldo (debet/kredit), waktu sekarang dan kolom home untuk mempermudah kembali ke halaman utama (home). Tabel yang ada pada buku besar akan secara otomatis menampilkan data yang telah diinput pada jumal umum dan menampilkan saldo akhir. Hal ini bertujuan mengurangi resiko salah posting dan salah hitung data transaksi pada buku besar.

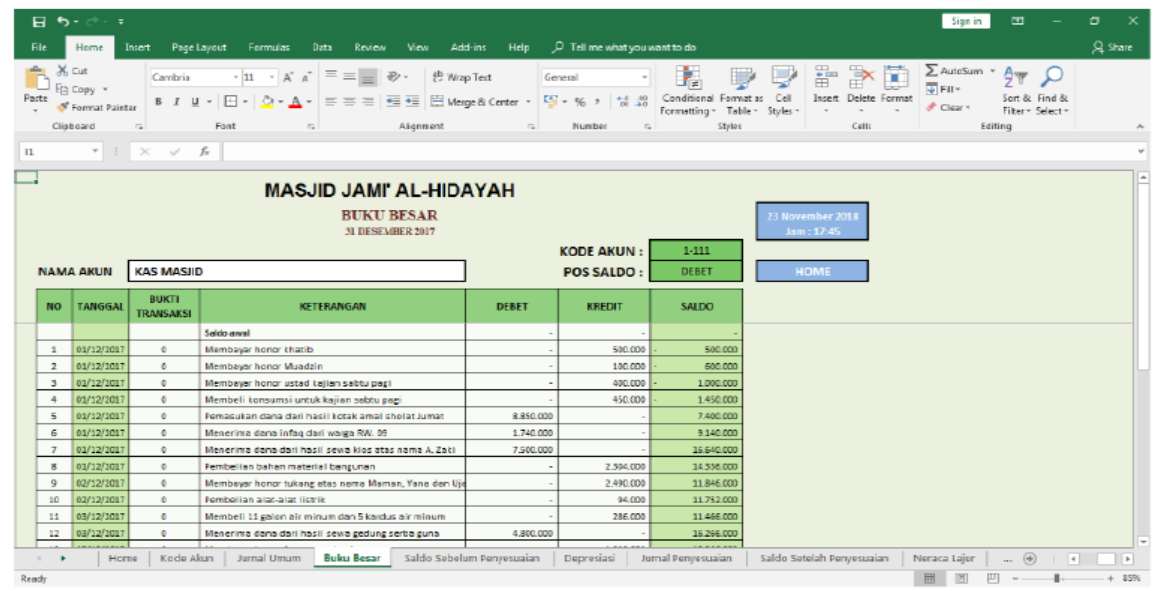

Gambar 4. Tampilan Buku Besar Excel Accounting

Saldo sebelum penyesuaian yang dibuat peneliti akan menampilkan secara otomatis saldo akhir yang muncul pada buku besar dari tiap-tiap akun. Saldo akhir tersebut akan otomatis dijumlahkan untuk mengetahui keseimbangan (balanced) dari total saldo yang dipos pada debetkredit. Hal ini akan mengurangi resiko salah posting dan salah hitung (human error).

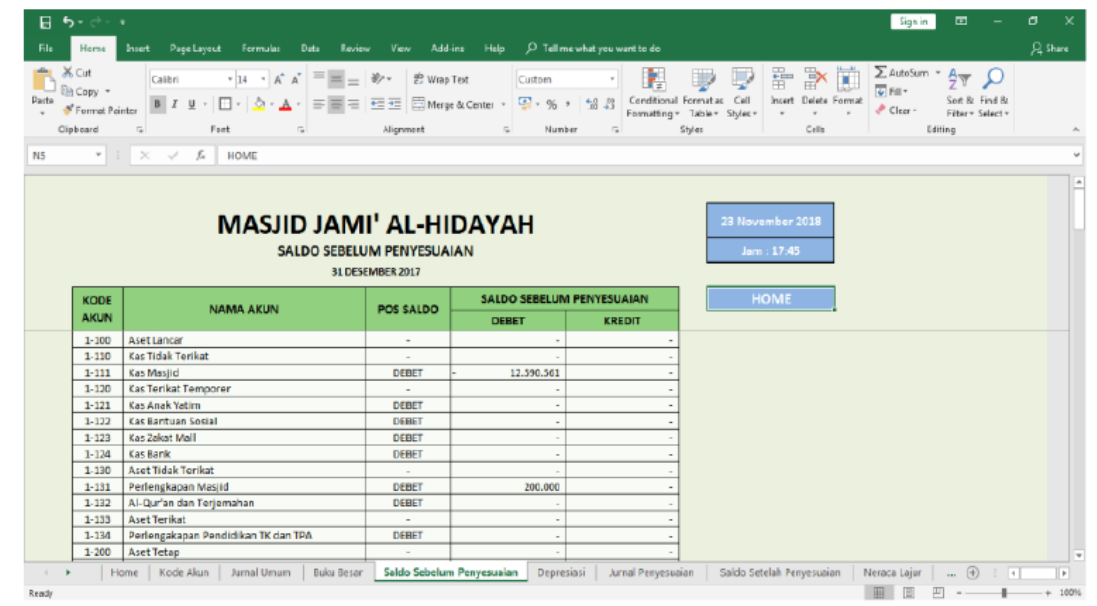

Gambar 5. Tampilan Buku Besar Saldo Sebelum Penyesuaian Excel Accounting 
Perhitungan depresiasi bertujuan untuk memudahkan perhitungan penyusutan sesuai dengan metode garis lurus. Pada sheet depresiasi terdapat tabel perhitungan penyusutan peralatan, penyusutan bangunan dan penyusutan kendaraan yang nantinya akan memunculkan nilai penyusutan pertahun dan perbulan secara otomatis. Munculnya nilai penyusutan pertahun dan perbulan secara otomatis bertujuan untuk mengurangi resiko kesalahan hitung. Selain itu, Sheet ini dibuat untuk memudahkan pembuat laporan keuangan agar lebih praktis dalam menghitung depresiasi. Sehingga tidak perlu membuka file baru untuk menghitung depresiasi karena sudah tersedia dalam sistem.

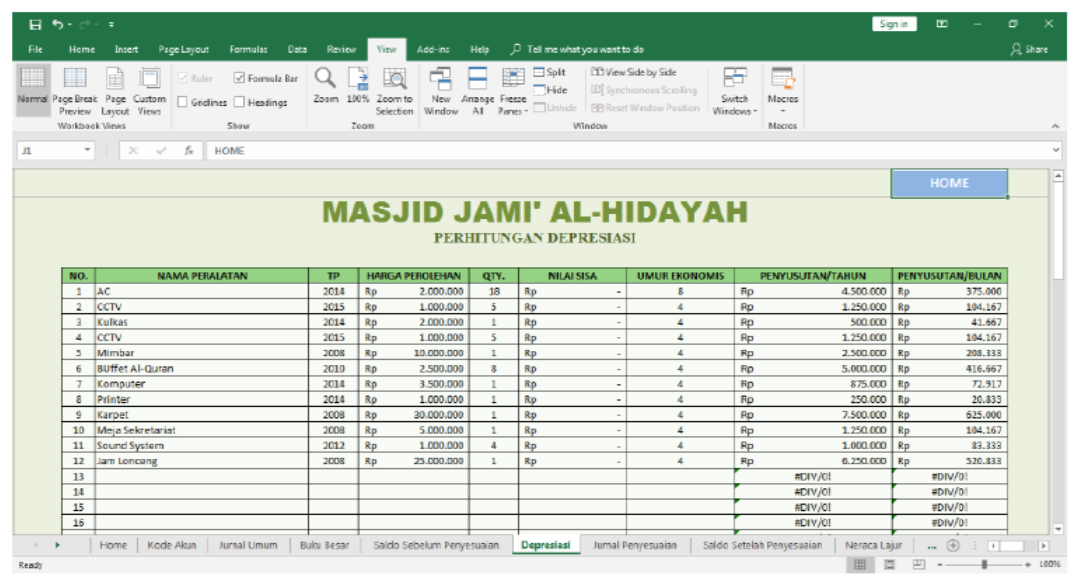

\section{Gambar 6. Tampilan Depresiasi Excel Accounting}

Tampilan jurnal penyesuaian tidak jauh berbeda dengan jurnal umum. Pada sheet jurnal penyesuaian terdapat kolom home, waktu sekarang dan tabel jurnal penyesuaian. Konsepnya sama seperti pada jurnal umum tanggal terdiri dari 2 kolom dimana kolom yang pertama tervalidasi dan kolom kedua akan terisi tanggal, bulan dan tahun secara otomatis mengikuti kolom pertama. Hal ini bertujuan untuk menghindari resiko salah penanggalan dalam transaksi. Kemudian ada kolom nama akun yang tervalidasi dan nomor akun/kode akun akan muncul otomatis setelah nama akun dipilih. Hal ini bertujuan untuk menghindari salah input data nama akun dan nomor akun. Selain itu hal ini juga akan mempercepat penjumalan.

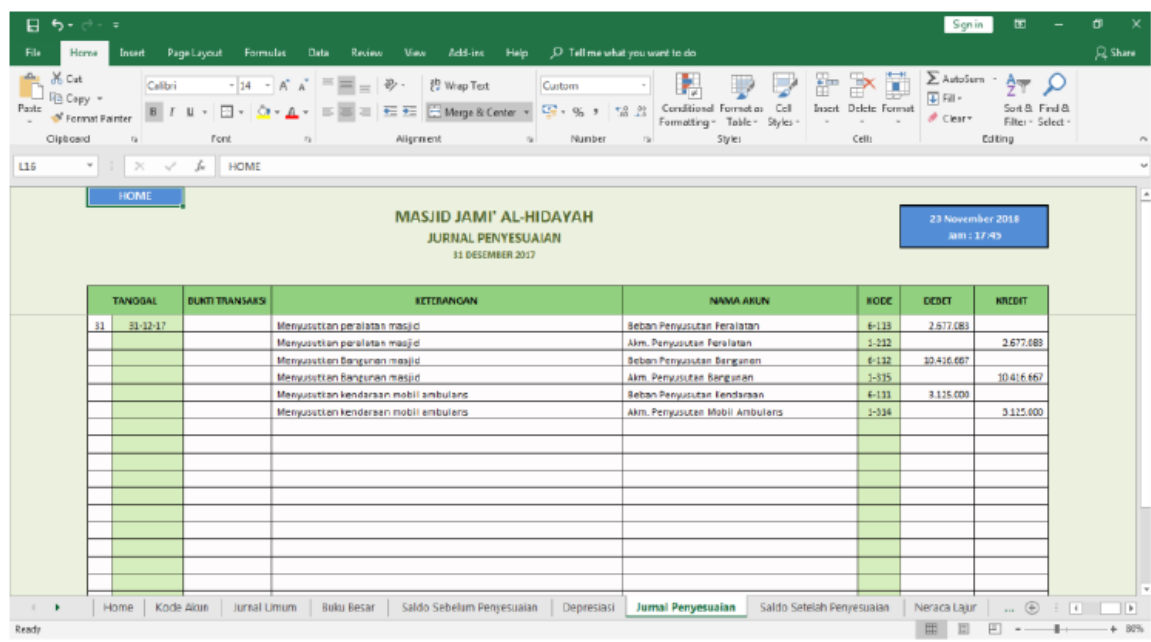

Gambar 7. Tampilan Jurnal Penyesuaian Excel Accounting 
Tampilan saldo setelah penyesuaian tidak berbeda dengan tampilan saldo sebelum penyesuaian. Pada sheet saldo setelah penyesuaian terdapat kolom home, waktu sekarang dan tabel saldo setelah penyesuaian. Saldo setelah penyesuaian akan memunculkan otomatis seluruh saldo yang dihitung hingga tahap penyesuaian. Hal ini bertujuan untuk menghindari resiko salah hitung dan posting nilai saldo pada saldo setelah penyesuaian. Selain itu hal ini akan mempermudah pekerjaan pengurus dan membuat pekerjaan pengurus lebih efektif dan efisien karena pengurus hanya mengecek keseimbangan.

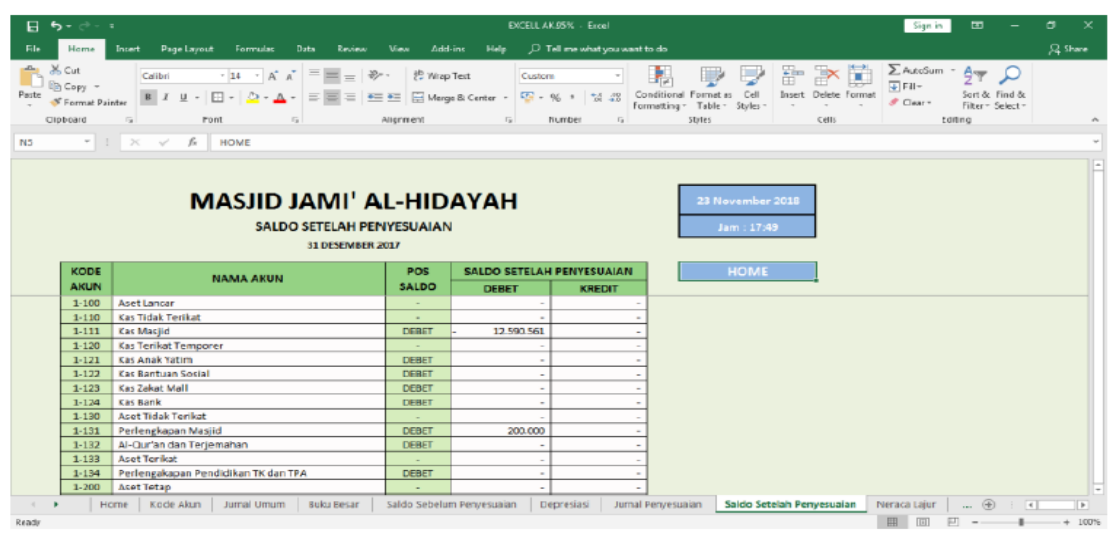

Gambar 8. Tampilan Saldo Setelah Penyesuaian Excel Accounting

Pada tampilan neraca lajur terdapat kolom home dan tabel neraca lajur. Informasi yang ada pada tabel neraca lajur adalah kolom kode akun, nama akun, pos saldo (debet/kredit) yang sudah ditentukan, saldo sebelum penyesuaian (muncul otomatis), penyesuaian (saldo otomatis muncul dari jurnal penyesuaian), saldo setelah penyesuaian (muncul otomatis), pos laporan (laporan aktivitas/laporan posisi keuangan) yang muncul otomatis mengikuti data yang di input pada sheet daftar perkiraan akun, laporan aktivitas dan laporan posisi keuangan.

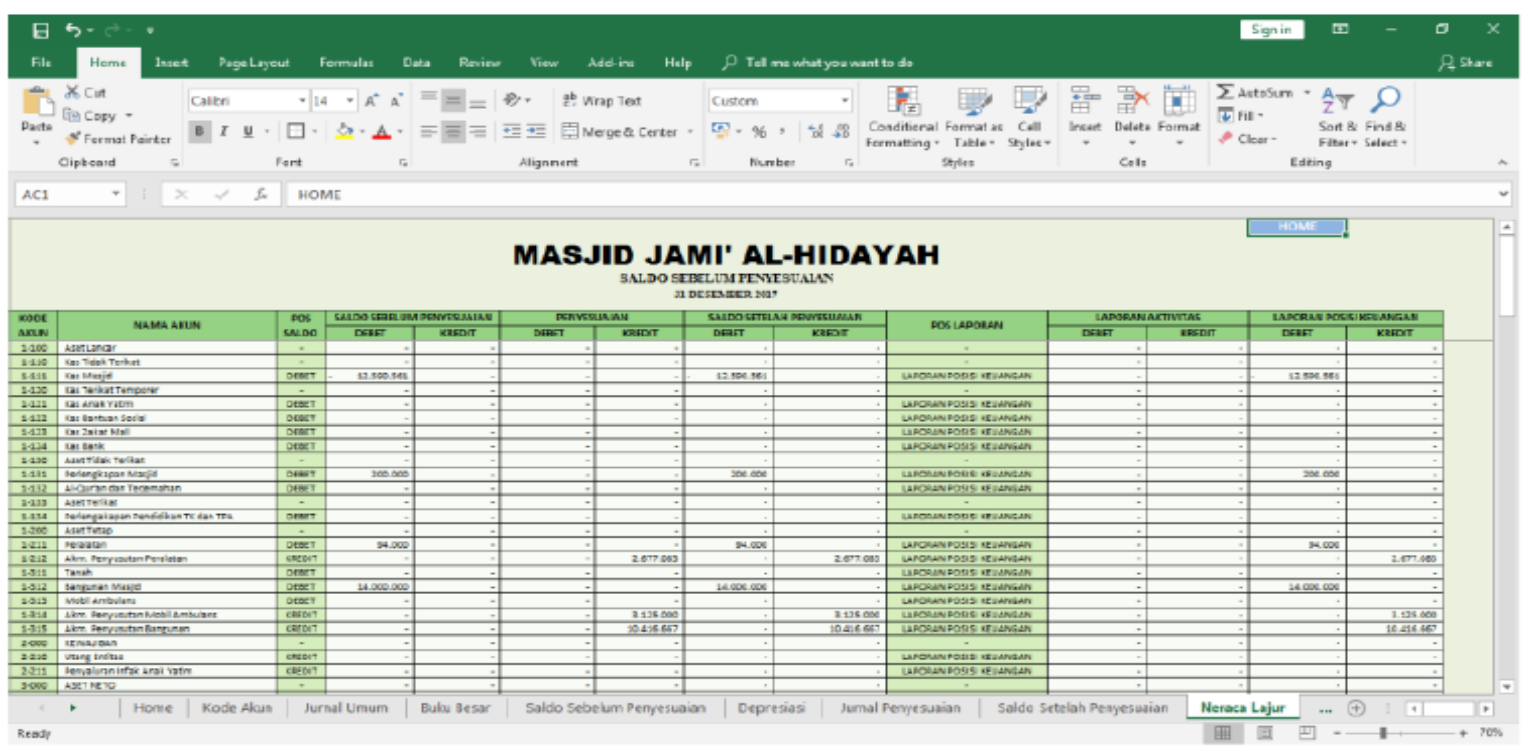

Gambar 9. Tampilan Neraca Lajur Excel Accounting 
Pada Gambar 9, kolom laporan aktivitas dan laporan posisi keuangan data akan dikelompokan secara otomatis mengikuti kolom pos laporan. Pada tabel bagian bawah terdapat kolom untuk mengetahui informasi keseimbangan dan selisih. Data yang muncul secara otomatis bertujuan untuk mengurangi resiko salah posting dan salah hitung serta akan mempercepat dalam pembuatan laporan keuangan.

Selanjutnya, pada sheet laporan aktivitas terdapat kolom home (halaman utama) dan tabel laporan aktivitas. Tabel laporan aktivitas menyediakan informasi mengenai kode akun (pendapatan/beban), nama akun, jenis akun (tidak terikat, terikat temporer, terikat permanen), jumlah masing-masing jenis akun dan kolom jumlah total.

Pada kolom bagian bawah terdapat informasi mengenai perubahan aset neto (jumlah pendapatan dikurang jumlah beban), aset neto awal tahun dan aset neto akhir tahun. Kode akun yang tervalidasi akan mengurangi resiko salah input. Selanjutnya nama akun dan jenis akun akan muncul otomatis ketika kode akun telah dipilih. Hal ini bertujuan untuk menghindari resiko salah posting dan hitung yang mungkin terjadi karena

faktor human error.

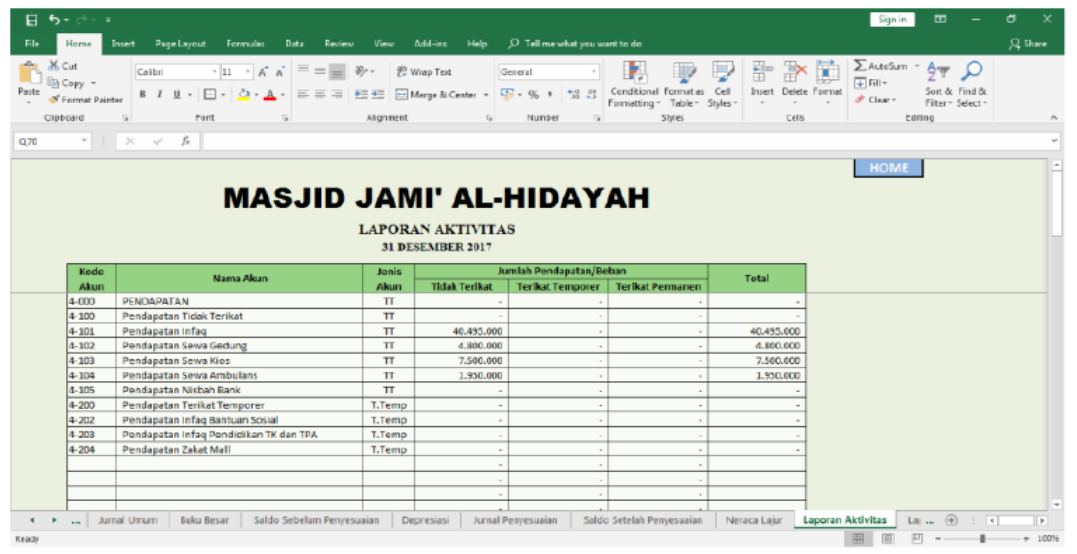

Gambar 10. Tampilan Laporan Aktivitas Excel Accounting

Pada sheet laporan posisi keuangan terdapat kolom home dan tabel laporan posisi keuangan. Tabel laporan posisi keuangan menyediakan informasi kode akun (aset, kewajiban dan aset neto), nama akun, jumlah akun dan jumlah total akun. Pengoperasiannya sama seperti laporan aktivitas, pada saat memasukan kode akun, maka secara otomatis nama akun dan saldo akan muncul.

Kode akun sudah tervalidasi untuk menghindari resiko salah memasukan nomor akun/kode akun. Nama akun dan saldo muncul otomatis bertujuan untuk mengurangi kesalahan posting dan hitungyang mungkin terjadi yang disebabkan oleh kesalahan manusia atau biasa disebut (human error). 


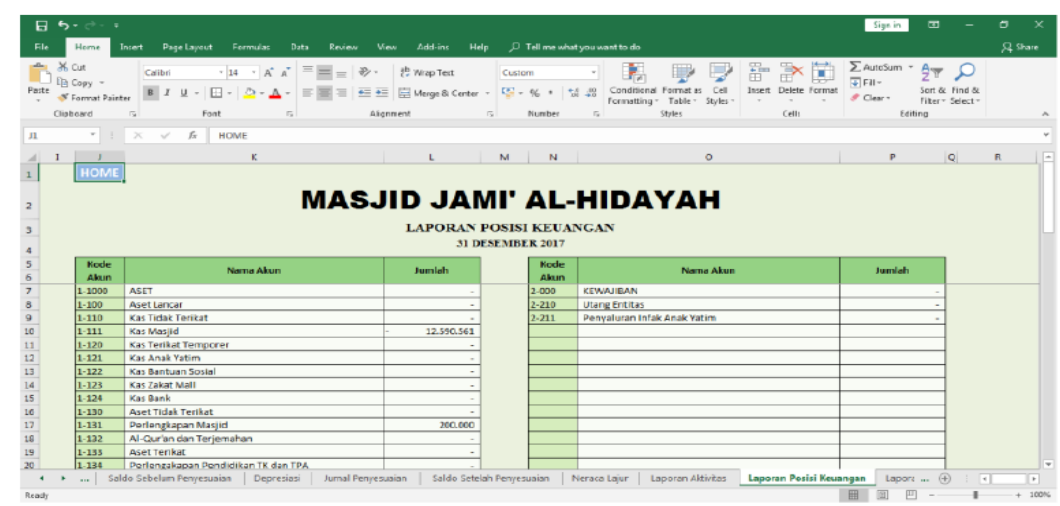

Gambar11. Tampilan Laporan Posisi Keuangan Excel Accounting

Pada sheet laporan arus kas terdapat kolom home (halaman utama) dan tabel laporan arus kas. Konsep dari laporan arus kas sama dengan laporan aktivitas dan laporan posisi keuangan. yaitu memasukan kode akun (tervalidasi) dan secara otomatis akan muncul nama akun beserta nominalnya. Hal ini bertujuan untuk mengurangi resiko salah posting dan hitung yang mungkin terjadi yang disebabkan oleh kesalahan manusia atau biasa disebut (human error).

Selain itu hal ini dapat mempermudah dan mempercepat pekerjaan pengurus dalam pembuatan laporan keuangan. Pada tabel arus kas terdapat informasi tentang aktivitas operasi, aktivitas investasi dan aktivitas pendanaan. Kemudian dari penjumlahan ketiga aktivitas tersebut didapat kenaikan/penurunan neto pada kas.

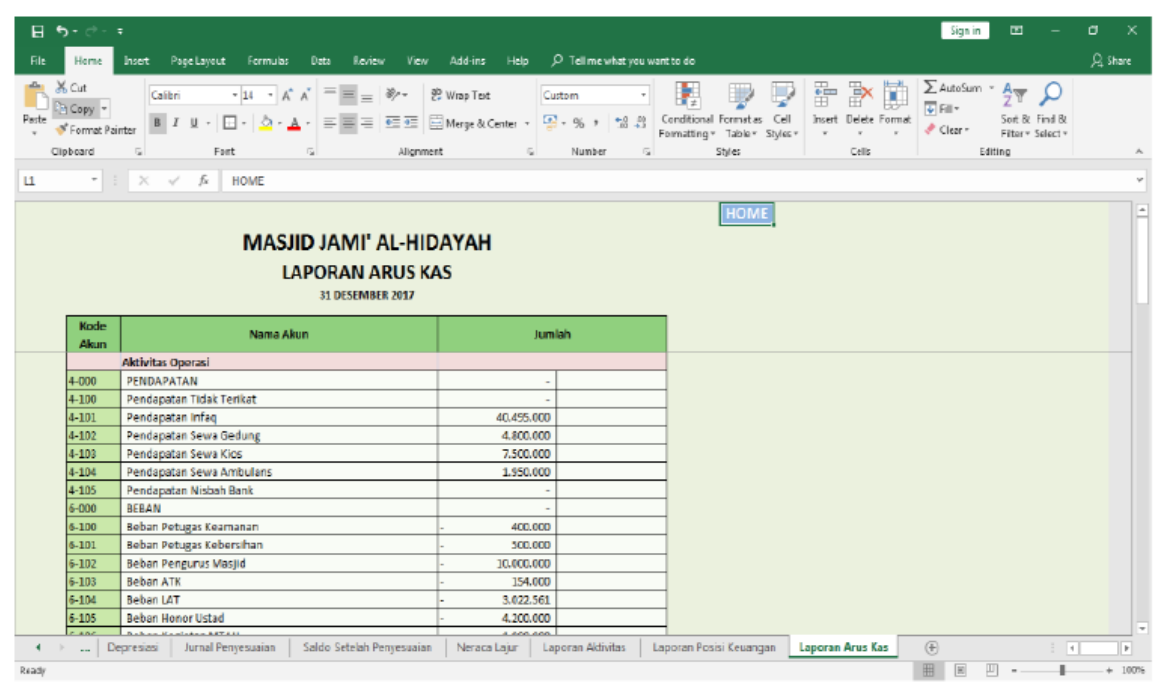

\section{Gambar 12. Tampilan Laporan Arus Kas Excel Accounting}

Jurnal penutup dibuat untuk menutup akun pendapatan, beban dan aset neto yaitu aset neto tidak terikat, aset neto terikat temporer, aset neto terikat permanen. Pada sheet jurnal penutup terdapat kolom home dan tabel jurnal penutup. Pada tabel jurnal penutup terdapat informasi tentang kode akun (tervalidasi), nama akun, jenis akun dan pos saldo yang dibalik penempatan debet dan kreditnya.

Kolom kode akun tervalidasi bertujuan untuk menghindari resiko salah memasukan data dan kolom nama akun, jenis akun dan saldo dibuat secara otomatis untuk menghindari resiko salah 
posting dan hitung. Hal ini diharapkan akan mempermudah dan mempercepat pekerjaan pengurus dalam pembuatan laporan keuangan masjid.

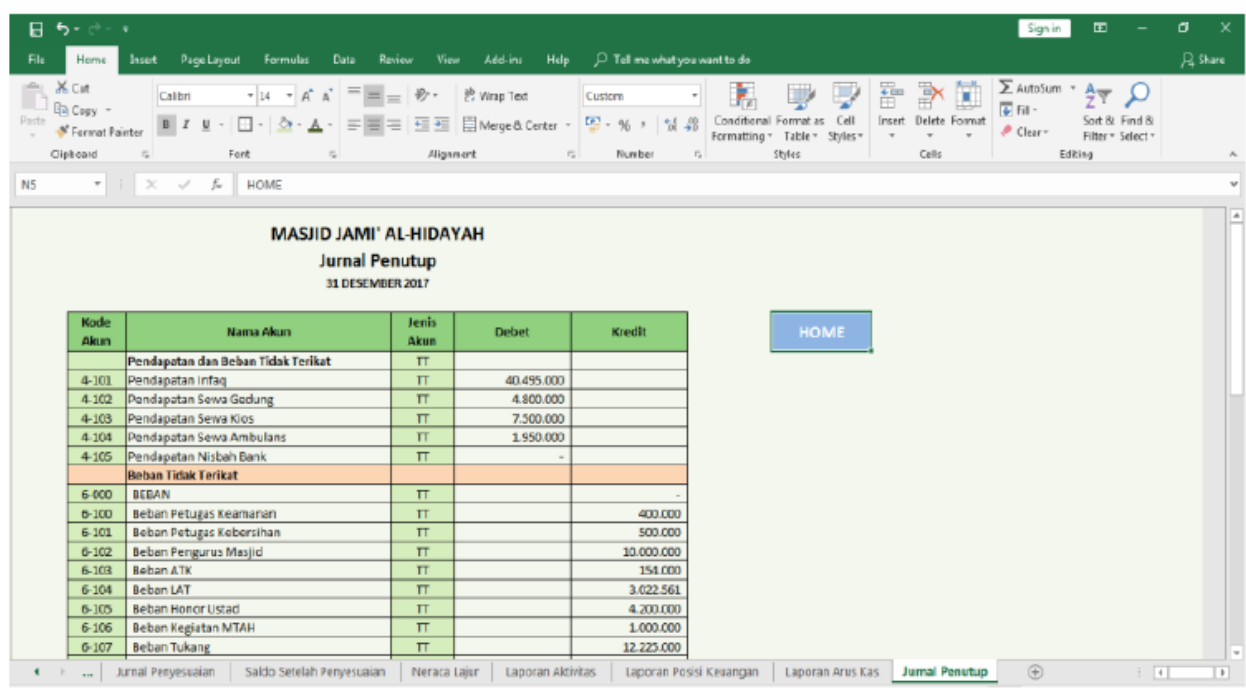

Gambar 13. Tampilan Jurnal Penutup Excel Accounting

Setelah tahap 2 selesai, kemudian tahap 3 yaitu evaluasi oleh pengguna merupakan tahap akhir dari perancangan penerapan sistem akuntansi ini. Berdasarkan hasil evaluasi oleh para pengurus, hasilnya menunjukkan bahwa pengurus masjid menyatakan PUAS dengan sistem akuntansi dengan alat bantu excel dan memberikan nilai 8 dari skala nilai 10, untuk fungsionalitas sistem, kemanfaatan sistem, dam kesiapan sistem.

\section{SIMPULAN}

Kegiatan pengabdian masyarakatini bertujuan untuk membantu pelaporan keuangan masjid agar lebih terstruktur dan transparan. Prosesnya terdiri dari 3 tahap, yaitu tahap pengumpulan data, tahap penyusunan dan implementasi teknis, dan tahap evaluasi. Hasilnya, pengguna sistem akuntansi dengan alatbantu excel merasa puas karena sistem dapat berfungsi dengan baik, dan bermanfaat bagi pengelola dana masjid dan bagi pengguna laporan keuangan masjid.

\section{UCAPAN TERIMA KASIH}

Terima kasih kami ucapkan kepada seluruh jajaran Pembina dan Pengawas, serta segenap Pengurus Masjid Jami' Al-Hidayah atas kerjasamanya untuk menjadinyakepercayaan masyarakat terhadap Laporan Keuangan Masjid terstruktur sesuai PSAK 45 dan transparan.

\section{REFERENSI}

Andarsari, P.R. 2016. Laporan Keuangan Organisasi Nirlaba (Lembaga Masjid). Jurnal Ekonomi Universitas Kadiri, 1(2), 143-152

Halim, Abdul dan Syam Kusufi, Muhammad. 2012. Teori, Konsep, dan Aplikasi Akuntansi Sektor Publik dari Anggaran hingga Laporan Keuangan dari Pemerintah hingga Tempat Ibadah. Jakarta : Salemba Empat.

Hanafi, R. 2015. Akuntabilitas dan Pengelolaan Keuangan di Masjid Melalui Pendekatan Fenomenologi (Studi Empiris Pada Masjid Nurusy Syifa' Surakarta). Naskah Publikasi 
Fakultas Ekonomi dan Bisnis Universitas Muhammadiyah Surakarta. Diunduh dari eprints.ums.ac.id/37119/1/Naskah\%20Publikasi.pdf.

Latif, A. 2014. Akuntabilitas dan Pengelolaan Keuangan di Masjid (Studi Kasus di Masjid Nurul Huda Kecamatan Polanharjo). Naskah Publikasi Fakultas Ekonomi dan Bisnis Universitas Muhammadiyah Surakarta. Diunduh dari eprints.ums.ac.id/32016/9/02.\%20Naskah\%20Publikasi.pdf.

Siskawati, Ferdawati, dan Surya. 2016. Bagaimana Masjid dan Masyarakat Saling Memakmurkan? Pemaknaan Akuntabilitas Masjid. Jurnal Multiparadigma, 7(1): 70-80 